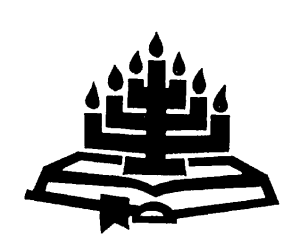

\title{
Woordspel en magspel in Daniël 2
}

\author{
H.J.M. van Deventer \\ Vakgroep Teologie \\ Skool vir Basiese Wetenskappe \\ Potchefstroomse Universiteit vir $\mathrm{CHO}$ \\ Vaaldriehoekkampus \\ VANDERBIJLPARK \\ E-pos: bybhjmvd@puknet.puk.ac.za
}

\begin{abstract}
Word-play and power-play in Daniel 2

This article investigates how word-play identified in the dialogue between the king and the wise counsellors in Daniel 2:2-12 contributes to the establishing of meaning in the narrative. After a broad description of issues related to the world "behind" the text, the article focuses on text-immanent aspects, as well as aspects related to an active reader of the text. It is indicated how wordplay creates polarisation among characters in the text as well as resolves the tension by introducing a Wholly Other and a different way of assessing such polarity.

\section{Opsomming}

Woordspel en magspel in Daniël 2

Hierdie artikel ondersoek hoe die woordspel wat in die dialoog tussen die koning en die wyse raadgewers in Daniël 2:2-12 geïdentifiseer word, 'n bydrae lewer tot die totstandkoming van betekenis in die vertelling. $\mathrm{Na}$ 'n algemene beskrywing van sake wat verband hou met die wêreld "agter" die teks, fokus die artikel op teksimmanente aspekte, asook aspekte wat verband hou met die aktiewe leser van die teks. Daar word aangetoon hoe woordspel polarisasie skep tussen karakters in die teks, maar hierdie spanning ook ophef deur die bekendstelling van 'n Gans Andere en 'n ander wyse waarop sodanige polarisasie beoordeel kan word.
\end{abstract}

\section{Inleiding}

Die vertelling in Daniël 2 toon kenmerke van wat as mantiese wysheid beskryf word. Die verband tussen apokaliptiek as literatuursoort, waarvan die boek Daniël 'n voorbeeld is, en die wysheidstradisie in Israel is reeds implisiet deur Eissfeldt (1965:529) gesuggereer: "it ... becomes 
clear that apocalyptic is closely associated with erudition" (my kursivering). Dit was egter Von Rad (1965:306) wat die volgende dapper stelling gemaak het: "the real matrix from which apocalyptic literature originates ... is Wisdom". Soos te wagte kon wees, het hierdie stelling gemengde reaksie uitgelok. Enersyds is dit sterk afgewys ten gunste van die tradisionele siening dat apokaliptiek uit die profetiese tradisie ontwikkel het (vgl. Von der Osten-Sacken, 1969). Andersyds is hierdie siening verder verfyn, onder andere deur 'n onderskeid te tref tussen didaktiese wysheid (van die Spreuke-tipe) en mantiese wysheid, wat betrekking het op die verstaan van die toekoms deur middel van tekens, waaronder drome (vgl. Müller, 1972:268-293).

Daniël 2 vertel in 'n soortgelyke trant as Genesis 41 van 'n Joodse karakter aan 'n vreemde hof wat in staat is om 'n droom oor toekomstige gebeure vir 'n vreemde vors uit te lê. Die Joodse karakter bewys homself (en sy God) op hierdie wyse "beter as" die vreemde vors se wysgere en word op grond van sy wysheid in 'n hoë posisie aan die koninklike hof aangestel (vgl. Gen. 41:39-41; Dan. 2:47-48).

Die huidige navorsingsveld en -belangstelling in die verstaan van die toekoms sluit nie direk aan by die histories-georiënteerde debat aangaande die bakermat van die apokaliptiek nie. Dit poog eerder om teen die agtergrond van die "mantiese wysheid"-matriks op 'n meer teksimmanente wyse na te gaan hoe die verteller by wyse van subtiele retoriese tegnieke enersyds 'n magspel tussen verskillende partye konstrueer, maar andersyds ook meedoen aan die magspel. Die fokus van die artikel is veral die gesprek tussen die koning en sy wyses (Dan. 2:212 ) in die konteks van die vertelling as geheel. Die meer fundamentele (teologiese) vraag wat hierdie artikel wil belig, hou verband met die moontlikheid (en wenslikheid daarvan) om 'n religieuse teks soos die Ou Testament op so 'n wyse te lees dat die polarisasie wat in die teks op een vlak geskep word, andersyds versag word.

\section{Teksimmanente ondersoeke en die boek Daniël}

Teksimmanente ondersoeke het begin as 'n poging om enkele teksimmanente tegnieke in 'n teks bloot te lê en daarop kommentaar te lewer. Die vertellings in die boek Daniël was al dikwels die voorwerp van sodanige studies. Arnold (1993) het byvoorbeeld gewys op die ironiese funksie van woordspel (נפק) in Daniël 5, asook op chiastiese ironie בעה) en (שכח) in Daniël 6. Wolters (1991) asook Brenner (1994) het gewys op die "toilethumor" in Daniël 5 wat opgesluit is in die "knope van sy [die koning se] lendene wat losraak", nadat koning Belsasar 'n hand gesien het wat teen die muur skryf. 
In soortgelyke trant kan verwys word na die studie van Avalos (1991) wat glimlag oor die komiese funksie van die lyste amptenare en musiekinstrumente wat in Daniël 3 aangetref word. Coxon (1986) het op sy beurt al die lyste in die vertellings in die boek Daniël onder die loep geneem en daarop gewys hoedat die herhaling van hierdie lyste, asook die "aanpassings" in die herhalings, vir retoriese en ironiese effek ingespan word. Good (1984) vind die klassieke U-patroon van die komedie terug in die verhale in Daniël, terwyl Shea (1985a en 1985b) wys op die chiastiese konstruksie van Daniël 4 en Daniël 5 na aanleiding van Lenglet (1972) se studie wat 'n soortgelyke struktuur in die groter Aramese deel van Daniël (hoofstukke 2-7) uitwys. Die doel met die huidige artikel was dus aanvanklik om 'n verdere bydrae tot hierdie soort teksimmanente studies met verwysing na die woordspel in Daniël 2 te lewer.

Indien die studie egter tot 'n beskrywing van enkele teksimmanente aspekte in 'n religieuse teks beperk bly, dan ontstaan die vraag na die werklike bydrae wat so 'n beskrywing lewer (vgl. Wuellner [1987:453] vir kritiek teen hierdie vorm van literêre kritiek in die naam van retoriese ontleding). Ten minste sal ook gewys moet word op 'n funksie wat 'n teksimmanente aspek vervul. In hierdie geval word van uit die teks na voor die teks beweeg. Met die klem op wat Wuellner (1987:461) die aktiewe leser noem, kan gevra word hoe woordspel in die teks deur 'n leser vertolk word? Hierdie artikel poog om iets weer te gee van die effek wat in die interaksie tussen teks en leser geskep word. Alhoewel die teks en die leser as twee van die drie aspekte van 'n geskrewe teks in hierdie artikel spesifieke aandag ontvang, kan die derde (historiese) aspek, wat dikwels ook met die outeur(s) in verband gebring word, nie genegeer word nie. Daarom word vervolgens kortliks verwys na sodanige saak "agter" die teks, naamlik 'n moontlike redaksiegeskiedenis van die vertelling in Daniël 2.

\section{3. 'n Redaksiegeskiedenis van Daniël 2}

'n Voorstel rondom die redaksie van Daniël 2 kan lig werp op die effek wat in die vertelde wêreld deur onder andere die woordspel in die gedeelte geskep word. Die vertelling in hierdie hoofstuk word beskou as een wat aanvanklik net soos die res van die vertellings in die boek (hoofstukke 2-6) onafhanklik van mekaar bestaan het, maar vroeg in die Hellenistiese tyd saamgevoeg en van 'n gemeenskaplike inleiding (hoofstuk 1) voorsien is. Tydens die vroeë regering van die Seleukiede heerser Antiogos Epifanes (175-163 v.C.) is Daniël 7 tot hierdie Aramese korpus toegevoeg en die Aramese bundel kon selfs 'n tyd lank afsonderlik gesirkuleer het alvorens die visioene van Daniël 8-12 bygevoeg is en Daniël 1 in Hebreeus vertaal is (Collins, 1993:38). 
Wat Daniël 2 betref, lyk dit ook asof die vertelling soos dit tans daar uitsien, ' $n$ uitbreiding op ' $n$ vroeëre verhaal is. Selfs in die huidige vorm lyk dit nie asof hierdie gedeelte die latere toevoeging van Daniël 1 tot die "Aramese bundel" verdiskonteer het nie. In hoofstuk 2 word Daniël, wat reeds in hoofstuk 1 bekendgestel is, byvoorbeeld weer aan die koning (en die leser) bekend gestel. lets soortgelyks word in hoofstuk 2 self aangetref as Daniël in vers 16 die koning, wat reeds sy eie wysgere se versoek om uitstel te kry, op boosaardige wyse van die hand gewys het, weereens versoek dat hy (Daniël) 'n bietjie tyd gegun moet word om die droom en sy uitleg bekend te maak. Wanneer die amptenaar Ariog Daniël egter in vers 25 aan die koning bekendstel, lyk dit asof die koning - ten spyte van hierdie vorige ontmoetings - Daniël nie ken nie. Dit val ook op dat vers 24 grammaties, narratologies, asook kronologies en logies op vers 12 volg (Hartman \& Di Lella, 1978:139). Dit lyk dus asof verse 13-23 'n latere toevoeging tot die vroeëre verhaal is.

In die huidige vorm is Daniël 2 konsentries gestruktureer met die sekondêre interlude waarna so pas verwys is, reg in die middel van die vertelling. Wanneer hier verwys word na 'n sekondêre toevoeging tot die teks, beteken dit nie (soos in die klassieke bronkritiek) dat hierdie toevoeging minder belangrik as die "oorspronklike vertelling" is nie. Barton (1996:52) wys die identifisering van hierdie redaksionele toevoegings juis uit as ' $n$ belangrike aanduiding van betekenis in die teks en in der waarheid van primêre belang. Hierdie feit word onderstreep deur die invoeging van die interlude op 'n sentrale plek in die primêre vertelling. Skematies kan dit soos volg weergegee word:

v. $1 \quad-\quad$ Inleiding (probleem - verontrustende droom) (A) $v v$. 2-12 - Nebukadnésar en wyse manne (probleem verdiep) (B)

vv. 13-23 - Interlude (God maak "geheim" aan Daniël bekend) (C)

vv. 13-16 - Daniël se inmenging

vv. 17-19 - Petisie en bekendmaking

vv. 20-23 - Doksologie

$v v$. 24-45a - Daniël en Nebukadnésar (probleem ontrafel) ( $\left.\mathrm{B}^{\prime}\right)$

v. $45 b \quad-\quad$ Slot (probleem opgelos) (A')

vv. 46-49 - Nebukadnésar en Daniël (slot uitgebrei) (vgl. B en C)

Na hierdie uiteensetting van 'n moontlike redaksiegeskiedenis van Daniël 2 verskuif die aandag vervolgens na 'n ander historiese aspek, naamlik 'n vormkritiese bestudering van die hoofstuk. Die doel daarvan is om die oortuigingseffek van die vertelling binne 'n bepaalde Sitz im Leben vas te stel. 


\section{Vertellyne in Daniël 2}

In Daniël 2 word 'n samevoeging van twee tipes vertellings (vorme) aangetref. Enersyds is die tipiese struktuur van 'n vertelling van stryd aan 'n koninklike hof (tale of court contest) in hierdie hoofstuk aanwesig (Collins, 1993:46). Hierdie strydvertellings begin gewoonlik met 'n probleem wat die koning het en eindig met die held in die verhaal wat deur die koning tot ' $\mathrm{n}$ posisie van hoë aansien verhef word. Benewens die strydvertelling en onafhanklik daarvan, vervul die droom en die uitleg van die droom in Daniël 2 volgens Goldingay (1989:41) ook 'n belangrike funksie.

In die vertelwêreld wat Daniël 2 skep, is die agtergrond die regering van koning Nebukadnésar van Babel tydens die Babiloniese ballingskap van Juda (v. 1). Hierdie koning droom verontrustende dinge. Die breëre tema van 'n koning wat onverstaanbare drome droom, word elders in die $\mathrm{Ou}$ Testament (Gen. 41), asook in buite-Bybelse bronne aangetref (Hartman \& Di Lella, 1978:143). Koninklike drome is volgens Collins (1993:155) in die Ou Nabye-Ooste as openbaringsmiddele beskou. Soos in Genesis 41 is die heidense vors se wyse raadgewers nie in staat om die droom uit te lê nie, maar word 'n Joodse vreemdeling gevind wat dit wel kan doen. Hierdie vreemdeling word dan ryklik beloon. In Daniël 2 is 'n gedeelte (vv. 13-23) op 'n sentrale plek in die vertelling ingevoeg wat die klem daarop laat val dat die God van die Joodse karakter ook die Openbaarder van geheime is en dat Hy die lof daarvoor moet ontvang. Hierdie skema bepaal die aandag by die breëre vertellyne wat ook teruggevind word in tekste van dieselfde literêre tipe wat handel oor stryd aan 'n koninklike hof tussen heidense amptenare en Joodse vreemdelinge. Die oortuigingseffek wat hoofstuk 2 in hierdie konteks sal hê, kan soos volg verwoord word: Tydens 'n tydperk van vreemde oorheersing sal God, aan wie alle lof toekom, sy dienaars begiftig met selfs bo-menslike vermoëns, waardeur hulle sukses sal behaal.

Hierdie uiteensetting verdiskonteer egter nog nie die inhoud en verklaring van die koning se droom nie. Hierdie aspek moet ook in die formulering van die oortuigingseffek in Daniël 2 in ag geneem word, omdat 'n tema binne 'n tema in hoofstuk 2 bestaan (Hartman \& Di Lella, 1978:142; Goldingay, 1989:41). Hierdie droom en verklaring stel 'n leser bekend aan die vier-ryke-skema wat weer in Daniël 7 aan die orde kom, en waarvolgens aardse regeerders vernietig sal word wanneer 'n finale Godsryk daargestel word.

Die verdere oortuigingseffek van Daniël 2 het dus betrekking op die ontrafeling van die koning se probleem. Hier word nie volledig aandag gegee aan die beeld en die betekenis daarvan nie, maar die effek in die 
vertelling kan soos volg weergegee word: God sal 'n einde aan heidense koninkryke bring.

Die oortuigingseffek van Daniël 2 hou dus verband met die gedagte dat God die heidense koninkryke sal uitwis en in die tussentyd sy dienaars in daardie koninkryke sal bystaan om sukses te kan behaal (vgl. Porteous [1965:37] wat ook albei hierdie elemente in die vertelling herken).

\section{5. 'n Retoriese situasie in Daniël 2}

Die bepaling en belang van 'n retoriese situasie in ' $n$ vertelling en die verskil tussen ' $n$ retoriese en historiese situasie is al belig (vgl. Van Deventer, 1999:462-464). In die huidige artikel word daarom net aandag gegee aan die probleem wat in die teks aan die orde gestel word, asook die belange van die implisiete outeur en wie die implisiete gehoor is. In die sentrale verse van hierdie hoofstuk (vv. 13-23) word vir die eerste keer weer verwys na die Joodse karakters wat in Daniël 1 bekendgestel is (v. 13). Die probleem wat die res van die wyses in hierdie vertelling in die gesig staar, word nou ook die Joodse karakters se probleem: hulle word ook gesoek om gedood te word.

Die kernprobleem wat hier belig word, is nie soseer die droom en die interpretasie daarvan (die vier ryke) nie, maar hoe dit menslik moontlik is om uit te vind wat die droom en interpretasie is. Die klem val in die sentrale deel (vv. 13-23) nie op die "wat" (inhoud) van die droom nie, maar op "hoe" die "wat" bekom word. Die Joodse karakters staan dus voor die probleem van hoe om aan die lewe te bly in die lig van 'n wrede bevel deur 'n koning wat Goldingay (1989:54) beskryf as onder andere "tyrannical, violent, suspicious, and unreasonable".

Net na die bekendstelling van God en feitlik reg in die middel van die interlude, meld die verteller byna in die verbygaan, met die gebruik van net ses woorde dat die "geheim geopenbaar" is. Die woordorde in vers 19 is opvallend: die werkwoord ("openbaar") in die eerste sin word aan die einde van die sin geplaas. Die klem wat geplaas word op hierdie ontknoping, word versterk deurdat dit die eerste keer is dat die woord גלה (openbaar) in die vertelling gebruik word. Behalwe dat die saak wat voor God gebring word (die geheim), van groter omvang as bloot 'n droom of uitleg is, is die aksie om dit op te los ook groter as die blote "bekend maak" (ידע חוה חו') daarvan.

Die outeur wil aan sy gehoor binne 'n hopelose (doodsbedreigende) situasie 'n antwoord voorhou wat betrekking het op hoe daardie situasie opgelos kan word. In hierdie vertelling was daardie antwoord suksesvol en die probleem is ontknoop. Terselfdertyd word die optrede van be- 
paalde karakters as inspirerende en prysenswaardige voorbeelde voorgehou $(2: 46,48)$.

Die retoriese situasie wat vir hierdie eenheid voorgestel word, hou verband met die outeur se doel om die gehoor te oortuig om God te midde van 'n lewensbedreigende krisis aan te roep om uitkoms te bewerk. Die ander gunstige elemente in hierdie vertelling, naamlik die uiteindelike totstandkoming van 'n finale Godsryk wat alle aardse koninkryke sal verwoes (Hartman \& Di Lella, 1978:143), asook God se beheer van die geskiedenis (toekoms en verlede) (Goldingay, 1989:56) is daarop gemik om die gehoor te oortuig van die outeur se primêre doel. Hierdie gehoor stel dalk - te midde van 'n uiters bedreigende situasie nie soveel belang in 'n toekomstige bedeling nie, maar wel in 'n antwoord op die vraag oor hoe om uit die betrokke situasie te kom. Die gedagte aan God se beheer van die geskiedenis en insig in die toekoms, gee dalk oortuigingskrag aan die oproep om Hom aan te roep, maar dit gee ook troos as daardie aanroep van God nie die situasie sou verander nie.

\section{Woordspel in Daniël 2:2-12}

\subsection{Daniël 2:2-12 in die konteks van die primêre vertelling}

$\mathrm{Na}$ die meer algemene oorsig oor die hoofstuk en die oortuigingseffek wat in die groter eenheid opgesluit is, word gefokus op die gesprek tussen die koning en sy wyses en die woordspel wat daarin opval. Soos reeds verduidelik, is hierdie gesprek nie die hooffokus van die hoofstuk nie, maar dra dit by tot die breëre oortuigingseffek wat hierbo bespreek is. Hieronder word 'n letterlike vertaling van die Hebreeus en Aramees weergegee sodat aspekte soos stilistiese en sintaktiese tegnieke uitgelig kan word (die woordorde is behou soos in die oorspronklike tale en koppeltekens tussen Afrikaanse woorde dui daarop dat dit in die oorspronklike een woord is). Ter wille van volledigheid word daardie deel van die primêre vertelling wat volg op die sentrale interlude vanaf vers 24 tot vers 30 ook weergegee (vgl. die skematiese voorstelling onder punt 3 hierbo).

(2:2) En-hy-het-gesê die-koning om-te-roep vir-die-waarsêer-priesters en-vir-die-besweerders en-vir-die-towenaars en-vir-die-Galdeërs om-bekend-te-maak (נגד) vir-die-koning sy-drome en-hulle-hetgekom en-hulle-het-gestaan voor die-koning.

(2:3) En-hy-het-gesê vir-hulle die-koning: 'n-droom het-ek-gedroom ensy-was-onrustig my-gees om-te-weet (ידעו) die-droom. 
(2:4) En-hulle-het-gespreek die-Galdeërs met-die-koning Aramees diekoning tot-ewigheid lewe sê (אמר) die-droom vir-jou-dienaars endie-uitleg sal-ons-bekend-maak (חוה).

(2:5) En-hy-het-geantwoord die-koning en-gesê vir-die-Galdeërs: diewoord van-my is-seker as nie julle-bekend-laat-word-vir-my (ידע) die-droom en-sy-uitleg die-ledemate sal-verander-word enjulle-huise afvalhoop hulle-geplaas-word.

(2:6) Maar-as die-droom en-sy-uitleg julle-bekend-maak (חוה) geskenke en-gawes en-eer groot sal-julle-ontvang van-my-kant-af daarom die-droom en-sy-uitleg maak-bekend-vir-my (חוה).

(2:7) Hulle-het-geantwoord 'n-tweede-maal en-hulle-het-gesê: diekoning die-droom hy-sal-sê (אמר) vir-sy-dienaars en-sy-uitleg salons-bekend-maak (חוה).

(2:8) hy-het-geantwoord die-koning en-gesê: sekerlik wetende (יעע) ek dat die-tyd julle kopende omdat julle-gesien-het dat seker-is vanmy die-woord

(2:9) dat as-die-droom nie julle-bekend-maak-vir-my (ידע) een-sy-is julle-vonnis en-'n-woord 'n-leuen en-wesende-sleg het-julle-ooreengekom om-te-sê voor-my totdat die-tyd verander-sal-word daarom die-droom sê vir-my en-ek-sal-weet (ידע) dat sy-uitleg julle-vir-my-sal-bekend-laat-word (חוה).

(2:10) en-hulle-het-geantwoord die-Galdeërs voor-die-koning en-gesê nie-daar-is 'n-mens op-die-aarde wat (die)woord van-die-koning hy-is-in-staat om-bekend-te-laat-word (חוה) daarom enige-koning groot en-magtig 'n-woord soos-hierdie nie gevra vir-enige-waarsêer-priester of-besweerder of-Galdeër

(2:11) en-die-woord wat-die-koning hy-gevra-het is-moeilik en-'n-ander nie daar-is wat sal-bekend-maak-dit (חוה) voor die-koning behalwe gode wat hulle-woning met-die-vlees nie dit-is.

(2:12) Omdat hierdie die-koning hy-het-kwaad-geraak en-woedend-geword baie en-hy-het-gesê om-dood-te-maak vir-alle wyses vanBabel.

(2:24) Omdat hierdie Daniël hy-het-ingegaan tot-Ariog wat hy-het-gestel die-koning om-dood-te-maak vir-die-wyses van-Babel hy-hetgegaan en-so het-hy-gesê-vir-hom vir-die-wyses van-Babel nie-jydoodmaak bring-my voor die-koning en-die-uitleg vir-die-koning sal-ek-bekend-maak (חוה).

(2:25) Toe Ariog het-gou-gemaak hy-het-laat-ingaan vir-Daniël voor diekoning en-so het-hy-gesê-vir-hom dat-ek-het-gevind 'n-man uit- 
die-seuns van-ballingskap van Juda wat die-uitleg vir-die-koning hy-sal-bekend-maak (יד').

(2:26) Hy-het-geantwoord die-koning en-gesê vir-Daniël wat sy-naam (is) Beltsasar is-dit-jy hy-kan om-bekend-te-maak-vir-my (ידע) diedroom wat-ek-gesien-het en-sy-uitleg.

(2:27) Hy-het-geantwoord Daniël voor die-koning en-gesê die-geheim wat-die-koning verlang nie die-wyses die-besweerders die-waarsêer-priesters die-astroloë kan om-bekend-te-maak (חוה) vir-diekoning.

(2:28) Maar daar-is 'n-god in-die-hemel wat-openbaar geheime en-hyhet-bekend-gemaak (ידע) vir-die-koning Nebukadnésar wat dit sal-wees in-die-einde van-die-dae u-droom en-die-gesigte van-uhoof op-u-bed hierdie (is) dit.

(2:29) U koning u-gedagte(s) op-u-bed hulle-het-opgegaan wat dit salwees agter hierdie en hy-wat-openbaar die-geheime hy-het-ubekend-gemaak (יד ע') wat-dit sal-wees.

(2:30) En ek nie in-wysheid wat-daar-is in-my uit-al-(die)-mense geheim hierdie is-geopenbaar vir-my maar tot-die-saak dat die-uitleg virdie-koning hulle-sal-bekend-maak (ידע) en-die-gesigte van-u-hart sal-u-ken (ידע).

\subsection{Die eerste deel van die primêre vertelling}

In die eerste deel van die primêre vertelling (vv. 2-12 - Nebukadnésar en wyse manne) neem die koning se droom 'n belangrike plek in. In verse 2-12 kom hierdie woord tien keer voor. In die Aramese deel van die teks (vanaf v. 4b) word "droom" en "uitleg" op een uitsondering na (v. 9a) in dieselfde konteks genoem. 'n Ander begrip wat ook dikwels in hierdie deel van die primêre vertelling herhaal word en saam met "droom" en "uitleg" voorkom, is "bekend maak". Die herhalingspatrone in hierdie deel laat die klem dus primêr val op die droom, die uitleg en die bekendmaking daarvan.

Behalwe die beskywings wat die verteller aan die begin (v. 2) en einde (v. 12) van hierdie deel van die primêre vertelling bied, bestaan die res van die diskoers uit die dialoog tussen die koning en die wyse manne. In die twee "vertelde" verse (vv. 2, 12) kom die woord "sê" wel voor, maar dan as 'n beskrywing van die bevele wat die koning gee. In vers 2 is die bevel dat die wyses moet kom om die droom "bekend te maak", terwyl die bevel in vers 12 is om die wyses "dood te maak". Die leser "hoor" as 't ware die gesprek tussen die koning en die wyses oor die probleem van die droom, die uitleg en die bekendmaak daarvan. Die diskoers word deur die bevele van die koning omraam, maar daarbinne kry elke party 
drie geleenthede om te praat, sonder enige inmenging deur die verteller. Die verteller maak dit met die beskrywings aan die begin en einde duidelik dat die koning die eerste en laaste woord (bevel) het. Hierdie gesagsrol van die koning in dié deel van die vertelling word deur die herhaalde gebruik van die woord "koning" (13 keer in 11 verse) beklemtoon. Daarteenoor word die gespreksgenote net vyf keer met die versamelterm "Galdeërs" genoem.

Die verteller ontwikkel die spanningslyn ook met behulp van woordspel rondom die begrip bekend maak. Die verteller gebruik die Hif'il van נגד in die Hebreeuse deel (v. 2) as vertel word van die bevel wat die koning heel aan die begin gee. Dit word opgevolg deur die gebruik van ידע (Qal inf.) in die volgende vers, maar hierdie keer word die woord in die mond van Nebukadnésar geplaas wanneer hy vir die wyses sê dat hy wil "weet" wat die droom is wat hy gehad het. Met die eerste oogopslag lyk dit bloot na die gebruik van 'n sinoniem, maar uit die res van die vertelling word dit duidelik dat die karakter, Nebukadnésar, iets anders vereis as wat die verteller in vers 2 wil laat blyk. Die wyses se dialoog wat volg (in Aramees), bring die polarisering tussen hulle en die koning in die oog wanneer hulle vra dat die koning sy droom moet vertel (אמר Pe'al imp.) en sê dat hulle daarna die uitleg sal bekend maak (חוה Pa'el impf.) (v. 4). In die volgende vers klaar die koning die misverstand deels op wanneer hy die straf aankondig as die droom en die uitleg nie bekend gemaak (דיע' - Haf'el impf.) word nie. Die woordspel duur voort wanneer hy voortgaan om die beloning te beskryf as die droom en uitleg wel bekend gemaak sou word (חוה - Haf'el impf.) word (v. 6), gevolg חוה deur die opdrag om die droom en uitleg nou bekend te maak (weer - Haf'el imp.).

Nebukadnésar se gebruik van חוה in die imperatief skep blykbaar weer onsekerheid by die wyses; daarom herhaal hulle die versoek van vers 4: die koning moet die droom vertel (אמר), dan sal hulle die uitleg bekend maak (חוה). Hierdie versoek word gevolg deur Nebukadnésar wat alle onsekerheid oor wat verwag word, uit die weg ruim. Hy gebruik die woord ידע drie keer in verse 8-9 waarvan een keer met die betekenismoontlikheid van "bekend maak" (twee keer word die Pe'al-vorm [met die betekenismoontlikheid "weet"] gebruik). Die strekking van die argument is soos volg: eers as die wyses die droom alleen bekend maak ('ידע), sal die koning weet (ידע) dat die wyses ook die (regte) uitleg bekend sal maak (חוה) (v. 9).

Behalwe dat die koning met hierdie derde redevoering van hom enige misverstand uit die weg ruim, dryf dit die spanning in hierdie deel van die 
vertelling tot 'n breekpunt. Sou die wyses op die een of ander wyse tog die droom kan bekend maak (ידע)? Hulle derde (en langste) redevoering (vv. 10-11) is ' $n$ wanhopige poging om die koning tog tot ander insigte te bring. Hulle hou vol om die woord חוה te gebruik, want dit is al waartoe hulle in staat is. Die redevoering bestaan uit drie stukke getuienis:

- geen mens kan die opdrag (saak - מלה) uitvoer nie (v. 10),

- daarom het geen koning nog so 'n opdrag (saak - מלה) vereis nie (v. 10), en

- die opdrag (saak - מלה) is moeilik en net gode sou dit kon uitvoer (v. 11).

Aan die einde van hierdie redevoering het sake skynbaar 'n dooiepunt bereik. In die vertelde wêreld vererg die koning hom vreeslik, moontlik juis vanweë die subtiele aandrang van die wyses op חוה en daarmee saam die implisiete beskuldiging teen hom dat hy onredelik optree.

Die gewelddadige reaksie van die koning waarvolgens alle wyses in Babel gedood moet word (v. 12), kom vir die leser as 'n skok. Die hiperboliese taalgebruik ("baie woedend", "alle wyses") in hierdie vertelde diskoers word deur die verteller ingespan in samehang met die karakterisering deur middel van dialoog in die voorafgaande verse (vgl. Kaiser \& Silva, [1994:73] in verband met hierdie gebruik van dialoog). Die verteller maak dit duidelik dat die beeld wat van Nebukadnésar as 'n onredelike mens geskep word, in kontras met die beredeneerdheid van die wyses soos wat hierdie karakters in die dialoog ontplooi, inderdaad 'n korrekte beeld is (vgl. ook Goldingay [1989:43] oor die karakterisering in hierdie vertelling).

Die primêre vertelling word onderbreek deur die sentrale interlude (vv. 13-23) waarna reeds verwys is. Die volle strekking van die woordspel in 2-12 word egter eers heeltemal duidelik as die res van die primêre vertelling (v. 24 e.v.) ook aan die orde kom.

\subsection{Die tweede deel van die primêre vertelling}

Die begin van die tweede deel van die primêre vertelling (v. 24) wat op die sentrale interlude (vv. 13-23) volg, vertoon 'n duidelike ooreenkoms met die einde van die eerste deel (v. 12) en herinner aan wat Alter (1987:28) as "resumptive repetition" beskryf. Die vertaling hierbo dui hierdie ooreenkoms aan wanneer gelet word op die sintaktiese ver-

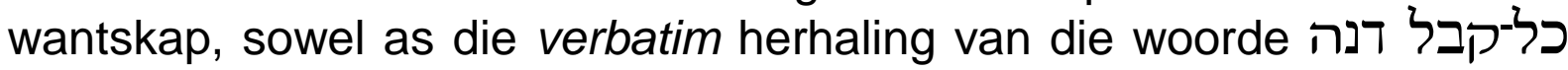
(aan die begin van albei sinne); מלכא (die koning); asook die herhaling 


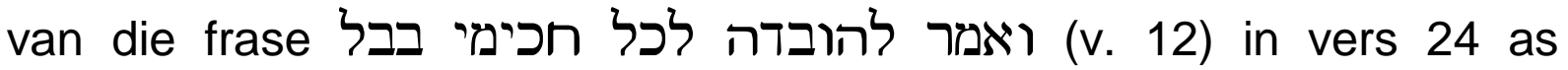
אמר־לה לחכימי בבל אל־תהובד. Dieselfde vertelmodus as wat in die eerste deel van die vertelling gebruik word, naamlik direkte rede, word in verse $24-26$ voortgesit (vgl. die herhaling van אמר).

Die tweede deel van die primêre vertelling sluit ook by die eerste aan wat die gebruik van die woordspeling rondom die begrip "bekend maak" betref. In die vorige deel het die koning dit uiteindelik ondubbelsinnig gestel dat hy vereis dat die droom, sowel as die interpretasie daarvan, bekend gemaak moet word (ידע), terwyl die wyses aangevoer het dat hulle slegs die interpretasie kan bekend maak (חוה). In hierdie deel van die vertelling word die vorige spanningslyn dadelik weer hervat wanneer Daniël aan Ariog sê dat hy slegs die uitleg aan die koning bekend sal maak (חוה) (v. 24). Die gedagte wat by die leser opkom, is dat dit nie gaan help nie, want die koning vereis meer. Alhoewel die sentrale interlude (vv. 13-23) reeds gesuggereer het dat die probleem deur God opgelos is, was die redaktor redelik bedag daarop om nie alles deur sy woordgebruik "weg te gee" nie. Die leser het in daardie gedeelte verneem dat God wel die geheim geopenbaar het (גלה) (v. 19) en dat Daniël God geprys het omdat die saak (מלה) van die koning bekend gemaak is (ידע) (v. 23). Daniël se gebruik van חוה in vers 24 skep egter weer spanning, veral as dit gekontrasteer word met Ariog se verdraaiing van Daniël se woord(e) voor die koning: hy deel die koning mee dat hy iemand gevind het wat die uitleg bekend sal maak (ידע).

Dit is dus nie verrassend dat die koning op sy beurt aan Daniël vra of hy eerstens in staat is om die droom en as 'n nagedagte "en sy uitleg" (einde van v. 26) bekend te maak (ידע) nie. Die woordorde, asook die hervat van die "droom"-tema wat die vorige keer in vers 9 (ook deur die koning) gebruik is, beklemtoon dadelik die vereiste wat die koning stel, in kontras met wat Daniël aanvanklik teenoor Ariog aangebied het (v. 24).

In sy antwoord aan die koning sluit Daniël op sy beurt aan by die interlude waarmee die leser reeds bekend is, wanneer hy na "die geheim" verwys wat die wyses nie bekend kon maak nie (חוה) (v. 27). Hierdie eerste deel van Daniël se redevoering (vv. 27-30) beklemtoon die goddelike oorsprong van die bekendmaking (ידע) van die geheim. Eerstens word die vroeëre suggestie van die wyses (vgl. v. 11) opgevolg deur die bekendstelling van die God van die hemel wat inderdaad kan doen wat die wyses erken het hulle nie in staat is om te doen nie (v. 28). Tweedens word die oorsprong van die droom ook tot God teruggevoer die droom is dus nie die koning se breinwerk nie (v. 29). Derdens stel Daniël homself hier op die agtergrond deur te verduidelik dat sy 
meerdere wysheid nie die rede is waarom die geheim juis aan hom bekend gemaak is nie (v. 30). Hierdie driemalige herhaling van die goddelike oorsprong word deur die woordkluster "geheime" en "bekend maak" in verse 28, 29 en 30 saamgebind.

\section{Magspel in Daniël 2}

Nadat gewys is op die woordspel in hierdie gedeelte van Daniël 2 wat verband hou met die bekendmaak van die droom en die betekenis, verskuif die aandag na die funksie van hierdie woordspel in die vertelling. Hierdie funksie word ook in verband gebring met 'n eietydse aktualisering van die teks en dit is uiteraard 'n subjektiewe saak, wat oop is vir meerdere interpretasies.

Die woordspel in Daniël 2 rondom die "bekendmaak" van die droom kan eerstens 'n literêre funksie hê: dit beteken dat hierdie woordspel 'n estetiese funksie vervul en die estetiese waarde van die vertelling verhoog. In hierdie geval waardeer die leser net die woordspel vir wat dit is, sonder om dit te interpreteer (soos byvoorbeeld die losmaak van die knope in Daniël 5).

Tweedens kan hierdie woordspel ook 'n meer ideologiese funksie hê: hiervolgens dien dit die doel van polarisering in die vertelling. In die eerste plek word die magtige koning teenoor die onmagtige magiërs gestel. Die koning as gesagsfiguur besit die mag oor lewe en dood en sal dit gebruik indien die magiërs nie aan sy eis voldoen om die droom en die interpretasie daarvan bekend te maak nie. Daar is ironie in opgesluit dat die magtige koning egter hulle hulp benodig (onmagtig is) om sy droom te verstaan en selfs te onthou.

$\mathrm{Na}$ die sentrale interlude (vv. 13-23) word die polarisasie met behulp van die woordspel voortgesit, maar nou staan die karakters van die koning en net een van die wyses (uit die Joodse ballinge) teenoor mekaar. In die ontknoping van die vertelling is dit nie Daniël, die Joodse karakter, wat die skaal in sy guns swaai ten koste van die koning nie. Die verteller se gesigspunt word subtiel ingebring wanneer Daniël juis weg van homself af wys na die God wat "geheime openbaar". Hier raak die verteller dus direk betrokke by 'n magspel van sy eie, naamlik om die leser te lei om hierdie "mag" agter die skerms raak te sien. God word deur die verteller geteken as 'n karakter wat op 'n totaal ander wyse optree as wat die koning vereis of as waartoe sy wyses (en selfs Daniël) in staat is. Deur die gebruik van die woord גלה ("openbaar") vir die beskrywing van die goddelike optrede, asook die "saak van die koning" wat verander na "die geheim" van die koning wys die verteller daarop dat ons hier met 'n buitengewone oplossing te doen het (in aansluiting by die 
gedagte van mantiese wysheid). Die Gans Andere gee 'n ander oplossing vir die probleem - en dit buite die polarisasie tussen menslike partye wat in die teks geskep is.

Dit val op dat op hierdie "mistieke" vlak daar nie 'n polarisasie van gode is nie, iets wat wel in die profetiese literatuur aangetref word (vgl. onder andere Jesaja 44:6-20). Die God van Daniël kom nie eksplisiet teenoor die gode van die koning te staan nie - in hierdie teks is die polarisasie net 'n kenmerk van die menslike (aardse) karakters. Trouens, die wyses het reeds vooruitgegryp na die goddelike oorsprong van enige oplossing vir die probleem van die koning wanneer hulle kollektief in v. 11 opmerk: "en-die-woord wat-die-koning hy-gevra-het is-moeilik en-'n-ander nie daar-is wat sal-bekend-maak-dit voor die-koning behalwe gode wat hulle-woning met-die-vlees nie dit-is". Die karakter van Daniël is egter die kanaal na hierdie goddelike bron van openbaring.

\section{Konklusie}

In hierdie artikel is gepoog om verskillende aspekte wat 'n rol speel in die verstaan van 'n teks, naamlik historiese, teksimmanente en leserverwante aspekte, sinvol saam te laat meewerk in die bepaling van betekenis. Gesien die unieke aard van die Bybel kan hierdie betekenis onder andere soos volg in 'n huidige konteks geaktualiseer word: in 'n gepolariseerde samelewing gaan menslike aansprake op 'n eksklusiewe metafisiese waarheid verdere polarisasie in die hand werk. Hierdie aansprake is dikwels slegs gegrond op die rasionele vermoëns van die mens. In Daniël 2 slaag die polarisasie wat deur die gebruik van 'n literêre tegniek tussen groepe mense geskep word - juis op sterkte van die rasionele moontlikheid, al dan nie - om aan die koning se opdrag te voldoen. Die sentrale interlude in Daniël 2 wys op 'n ander weg uit hierdie polarisasie wat die rede so graag skep (moontlik vs. onmoontlik; eenvoudig reg vs. eenvoudig verkeerd). Uit hierdie interlude blyk dit dat die stil word voor 'n Gans Andere, asook die kreatiewe en verbeeldingryke luister na 'n antwoord wat die polariserende menslike rede te bowe gaan, hierdie polarisasie kan teenwerk en daartoe meewerk dat God die lof en eer ontvang.

\section{Bibliografie}

ALTER, R. 1987. Introduction to the Old Testament. (In Alter, R. \& Kermode, F., eds. The literary guide to the Bible. Cambridge, Ma. : Belknap-Harvard. p. 11-35.)

ARNOLD, B.T. 1993. Wordplay and narrative techniques in Daniel 5 and 6. Journal of Biblical Literature, 112(3):479-485.

AVALOS, H.I. 1991. The comedic function of the enumerations of officials and instruments in Daniel 3. Catholic Biblical Quarterly, 53:580-588. 
BARTON, J. 1996. Reading the Old Testament. Method in biblical study. 2nd Edition. Louisville : Westminster/John Knox Press.

BRENNER, A. 1994. Who's afraid of feminist criticism? Who's afraid of Biblical humour? The case of the obtuse foreign ruler in the Hebrew Bible. Journal for the Study of the Old Testament, 63:38-54.

COLLINS, J.J. 1993. A commentary on the book of Daniel (Hermeneia). Minneapolis : Fortress.

COXON, P.W. 1986. The "list" genre and narrative style in the court tales of Daniel. Journal for the Study of the Old Testament, 35:95-121.

EISSFELDT, O. 1965. The Old Testament. An introduction. (Translated by P.R. Ackroyd.) New York : Harper \& Row.

GOLDINGAY, J. 1989. Daniel. (WBC) Dallas : Word Books.

GOOD, E.M. 1984. Apocalyptic as comedy: the book of Daniel. Semeia, 32:41-70.

HARTMAN, L.F. \& DI LELLA, A.A. 1978. The book of Daniel. (AB) New York : Doubleday.

KAISER, W.C. \& Silva, M. 1994. An introduction to biblical hermeneutics. Grand Rapids : Eerdmans.

LENGLET, A. 1972. La structure litteraire Daniel 2-7. Biblica, 53:69-90.

MÜLLER, H-P. 1972. Mantische Weisheit und Apokalyptik. (In Anderson, G.W., ed. Congress volume, Uppsala 1971. Leiden : Brill. p. 268-293.)

PORTEOUS, N.W. 1965. Daniel. (OTL) London : SCM.

SHEA, W.H. 1985a. Further literary structures in Daniel 2-7: an analysis of Daniel 4. Andrews University Seminary Studies, 23(2):193-202.

SHEA, W.H. 1985b. Further literary structures in Daniel 2-7: an analysis of Daniel 5. Andrews University Seminary Studies, 23(3):277-295.

VAN DEVENTER, H.J.M. 1999. Retoriese kritiek en die interpretasie van die Ou Testament. In die Skriflig, 33(4):447-467.

VON DER OSTEN-SACKEN, P. 1969. Die Apokalyptik in ihrem Verhältnis zu Prophetie und Weisheit. München : Kaiser.

VON RAD, G. 1965. Old Testament theology. Vol. 2. (Translated by D.M.G. Stalker.) Edinburgh : Oliver \& Boyd.

WOLTERS, A. 1991. Untying the king's knots: physiology and wordplay in Daniel 5. Journal of Biblical Literature, 110(1):117-122.

WUELNER, W. 1987. Where is rhetorical criticism taking us? Catholic Biblical Quarterly, 49:448-463.

\section{Kernbegrippe:}

Daniël 2

teksimmanente eksegese

woordspel in die Bybel

\section{Key concepts:}

Daniel 2

text immanent exegesis

wordplay in the Bible 
